Вісник Дніпропетровського університету. Серія: геологія, географія. 2016. 24 (1), 83-90.

Vìsnik Dnìpropetrovs'kogo unìversitetu. Serîa geologîa, geographìa

Dnipropetrovsk University Bulletin. Series geology, geography. 2016, 24 (1), 82-89.

doi: $10.15421 / 111612$

http://geology-dnu.dp.ua

УДК 330.341:332.12

\title{
Вплив інституціональних чинників на розвиток і формування господарського потенціалу Карпатського регіону
}

\section{Г.В. Машіка}

Мукачівський державний університет, Мукачеве, Украӥна, e-mail: mashika.g.v.@i.ua

Досліджено особливості впливу інституціональних факторів на формування і розвиток господарського потенціалу Карпатського регіону. Підкреслюється, що аналіз впливу інституціональних чинників на економічний розвиток регіонів - невід'ємна частина досліджень різних міжнародних економічних організацій. Для обгрунтування напрямів і набору інституціональних показників аналізу застосовано концепцію «інституціональних матриць». У ході дослідження виявлено значне відставання Карпатського регіону від середньо украӥнських показників соціально-економічного розвитку: ВРП, ВРП на душу населення, показників розвитку малих підприсмств, економічної активності населення, середнього рівня заробітної плати і доходів на душу населення, інвестиційної привабливості та ін. Зроблено висновки про неефективне використання конкурентних переваг регіону, зокрема, широкого спектра напрямів транскордонного співробітництва з Угорщиною, Молдовою, Польщею, Румунією, Словаччиною. Наголошено на необхідності посилення інвестиційної привабливості регіону, ефективності ринку праці, всілякої підтримки розвитку малого підприсмництва у сфері торгівлі, сільському господарстві, будівництві, індустрії туризму шляхом упровадження принципів сталого розвитку.

Ключові слова: господарський потенціал, інституціональне середовищуе, інституціональні чинники, Карпатський регіон, регіональний розвиток.

\section{Impact of institutional factors on formation of economic development and potential of Carpathian region}

\section{H.V. Mashika \\ Mykachevo State University, Mykacheve, Ukraine, e-mail: mashika.g.v.@i.ua}

The main purpose of the article is to assess the impact of institutional factors on the formation and development of the economic potential of the Carpathian economic region. The study used scientific methods, in particular: the methods of theoretical generalization - to summarize the theoretical foundations of the functioning of the region's economic potential; systems approach - to support the full impact of institutional factors on the formation and development of the region's economic potential; the concept of "institutional matrix" - to select a set of trends and institutional performance analysis; economic and statistical methods - to determine the dynamics of socio-economic development of Ukraine and the Carpathian economic region. Analysis of the impact of institutional factors on the development of the economic potential of the economy and regions is an integral part of the research of many international economic organizations such as the Doing Business (World Bank \& IFC); Corruption Perceptions Index (Transparency International); Worldwide Governance Indicators (World Bank). In this study were analyzed by statistical data that characterize the level of socio-economic development (gross regional product gross regional product per capita, etc.) moreover, the degree of development of market institutions in Ukraine and the Carpathian region of small business, market competition, labor market efficiency, exchange and financial market institutions. It was found a significant backlog of average Ukrainian Carpathian region of the socio-economic development. The conclusion of inefficient use of the competitive advantages of the region - a wide range of cross-border cooperation with Moldova, Hungary, Slovakia, Poland, Romania. They stressed the need to increase the investment attractiveness of the region, the full support of small business in trade, agriculture, construction, tourism industry through the introduction of sustainable development principles. The findings are the basis for solving practical problems of formation and development of the economic potential of the Carpathian region; improve the efficiency of the labor market, the business sector, the growth of incomes of local budgets, which is especially important in the context of decentralized regions.

Keywords: economic potential, the institutional environment, institutional factors, Carpathian region, regional development. 
Вступ. Соціально-політичні події, що відбулися в 2014 - 2015 pp. в Україні, викликали серйозні зміни в соціально-економічному розвитку країни та iii регіонів: скорочення обсягів виробництва, зниження інвестиційної привабливості, знецінення доходів населення в результаті девальвації національної грошової одиниці, зростання безробіття, значну трудову міграцію населення тощо.

3 іншого боку, посилення євроінтеграційних прагнень України покладає на регіони відповідальність за впровадження європейських принципів сталого просторового розвитку, інтенсифікацію єврорегіонального співробітництва, реалізацію принципу децентралізації влади.

У цих умовах великого значення набуває вивчення особливостей впливу інституціональних факторів на формування і розвиток господарського потенціалу регіону.

Дослідженням теоретичних засад формування і розвитку соціально-економічного потенціалу України та іiі регіонів займалися такі українські вчені, як А. Амоша, Б. Данилишин, М. Долішній, С. Дорогунцов, С. Злупко, В. Кравців, І. Лукінов, С. Лучик, А. Мазур, О. Мілашовська, І. Михасюк, М. Чумаченко та інші.

Незважаючи на значну кількість наукових публікацій, в більшості з них досліджуються загальні проблеми формування і розвитку потенціалу країни i регіонів. Вивченню впливу інституціональних факторів на формування і розвиток господарського потенціалу регіону, а також дослідженню особливостей розвитку Карпатського економічного регіону приділяється недостатня увага.

Мета статті полягає в оцінюванні впливу інституціональних чинників на формування і розвиток господарського потенціалу Карпатського економічного регіону.

Матеріал і методи досліджень. Існує безліч теоретичних концепцій, що пояснюють сутність і роль потенціалу в економіці. Одні вчені дотримуються думки, що потенціал - це сукупність необхідних для функціонування або розвитку системи різних ресурсів. Інші вважають, що потенціал слід розглядати як систему факторів (умов, складових), котрі забезпечують досягнення цілей. Також існує думка, що потенціал - це цілісне вираження сукупних можливостей для виконання нових завдань (Libanova, Hvesik, 2014).

Економічний потенціал господарського механізму визначається системою основних форм, методів $\mathrm{i}$ важелів використання економічних законів, вирішення існуючих соціально-економічних суперечностей, реалізацією відносин власності, розвитку людини та іiі потреб і забезпеченням узгодження функціонування всіх елементів економічної системи в усіх сферах суспільного відтворення (Semenov, 2008).

Саме тому економічний (господарський) потенціал регіону складається з багатьох компонентів, які можуть бути названі відповідними потенціалами: природно-ресурсного, виробничого, трудового, наукового, фінансового, інвестиційного, інституціонального, інноваційного та інших, кожен 3 яких має складну структуру і перебуває в органічному взаємозв'язку і у взаємодії з іншими (Doroshenko, 2006).

Взаємодія структурних елементів господарського потенціалу регіону відбувається відповідно до норм і правил та здійснюється за допомогою організаційних механізмів і структур, які в сукупності утворюють регіональне інституціональне середовище.

Інституціональним середовищем $€$ сукупність політичних, соціальних і економічних інститутів. Зауважимо:інститути - це правила, механізми, які забезпечують їх виконання, і норми поведінки, які структурують взаємодії між раціональними економічними агентами. Основне завдання інститутів - забезпечити ефективність взаємовідносин економічних агентів, зокрема, знизити їх транзакційні витрати, невизначеність і ризики під час прийняття рішень.

Під інституціональними чинниками розвитку розуміють вплив інститутів ринкової економіки, тобто систему заходів, які змінюють відносини власності, а також систему управління господарства, шляхом заміни адміністративних важелів економічними, підтримують конкурентне середовище, формують організації та установи ринкового типу.

Інституціональні чинники значно впливають на рівень соціально-економічного розвитку як окремого регіону, так і країни в цілому. Тому їх аналіз $є$ складовою частиною досліджень багатьох міжнародних економічних організацій, наприклад, DoingBusiness (WorldBank\& IFC); CorruptionPerceptionsIndex (TransparencyInternational); WorldwideGovernanceIndicators (WorldBank) (Soldak, 2014).

Починаючи з 2011 року в Україні проводиться повноцінний розрахунок індексу конкурентоспроможності регіонів, що базується на методології розрахунку глобального індексу конкурентоспроможності Всесвітнього економічного форуму. Аналіз сучасного стану та напрямків розвитку інститутів у регіонах $€$ одним із 12 базових складових індексу, тому що якість інституціонального середовища істотно впливає на конкурентоспроможність і економічне зростання. Воно позначається на інвестиційних рішеннях і ор- 


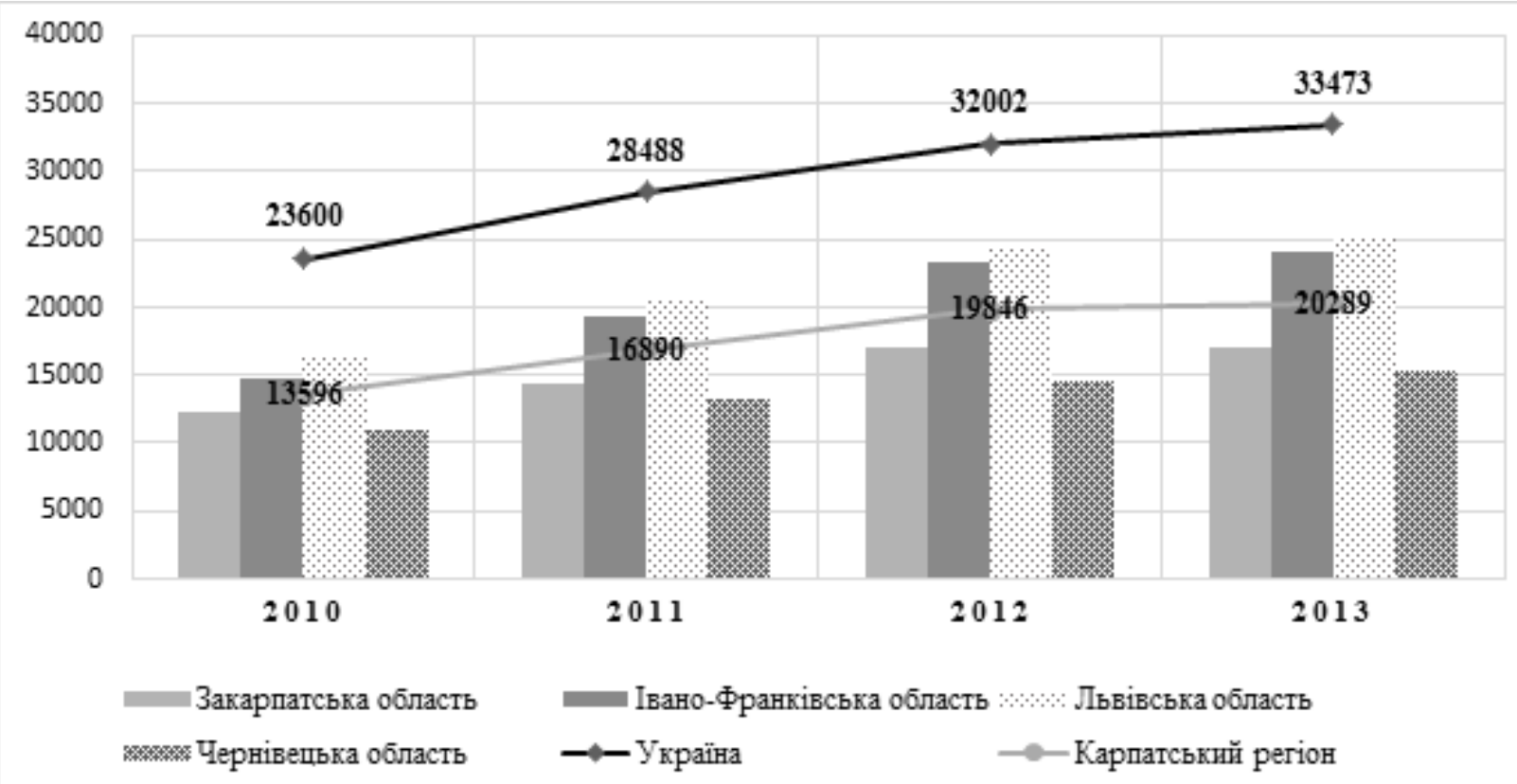

Рис.1. ВРП України і Карпатського регіону у розрахунку на одну особу, грн.

ганізації виробництва, а також впливає на те, яким чином суспільства розподіляють вигоди і несуть витрати з реалізації програм і стратегій розвитку («Otchet o konkurentosposobnosti regionov Ukrainyi 2013», 2013).

Для систематизування показників, які характеризують рівень інституціональної спроможності в регіоні, доцільно використовувати концепцію “інституціональних матриць” і виділити такі групи показників: “Інститут приватної власності” (права власності, питома вага МП в загальній кількості підприємств і їх частка в обсязі реалізованої продукції); "Інститут прибутку” (питома вага підприємств, які отримали прибуток, рентабельність операційної діяльності підприємств); “Інститут конкуренції” (інтенсивність конкуренції, ступінь монополізації ринку, конкурентні переваги); “Інститут найму праці” (ефективність ринку праці, створення робочих місць); "Інститут обміну" (індекс забезпеченості регіону підприємствами торгівлі та харчування, індекс роздрібного товарообігу); “Інститут фінансового ринку"(Soldak, 2014).

Результати та їх аналіз. Проаналізуємо вплив інституціональних чинників на розвиток Карпатського економічного регіону, до якого відносять територію Львівської, Івано-Франківської, Закарпатської та Чернівецької областей.

Інтегральним показником оцінки економічного потенціалу господарського комплексу регіону є валовий регіональний продукт (ВРП). Питома вага Карпатського регіону в ВРП України незначна $і$ коливається від 8\% у 2010 році до 8,7\% у 2013 році (табл. 1).

Серед областей Карпатського регіону найбільш економічно розвинутою можна вважати Львівську. Ïї ВРП за 2010 - 2013 рр. зріс на 52\% (з 41655 млн грн до 63329 млн грн) («Valoviy regionalniy produkt za 2013 rik», 2013), що перевішує темп приросту ВРП України (40\%) за аналізований період.

Таблиия 1

Валовий регіональний продукт за 2010 - 2013 рр.

\begin{tabular}{|c|c|c|c|c|c|c|c|c|}
\hline & \multicolumn{2}{|c|}{$\mathbf{2 0 1 0} \mathbf{p .}$} & \multicolumn{2}{c|}{$\mathbf{2 0 1 1} \mathbf{p .}$} & \multicolumn{2}{c|}{$\mathbf{2 0 1 2} \mathbf{p .}$} & \multicolumn{2}{c|}{$\mathbf{2 0 1 3}$ p. } \\
\hline & млн грн & $\%$ & млн грн & $\%$ & млн грн & $\%$ & млн грн & $\%$ \\
\hline Україна & 1082569 & 100 & 1302079 & 100 & 1459096 & 100 & 1522657 & 100 \\
\hline Закарпатська обл. & 15299 & 1,4 & 18054 & 1,4 & 21404 & 1,5 & 21400 & 1,4 \\
\hline Івано-Франківська обл. & 20446 & 1,9 & 26752 & 2,1 & 32286 & 2,2 & 33196 & 2,2 \\
\hline Львівська обл. & 41655 & 3,8 & 52103 & 4,0 & 61962 & 4,3 & 63329 & 4,2 \\
\hline Чернівецька обл. & 9892 & 0,9 & 11969 & 0,9 & 13166 & 0,9 & 13757 & 0,9 \\
\hline Карпатський регіон & 87292 & 8,0 & 108878 & 8,4 & 128818 & 8,9 & 131682 & 8,7 \\
\hline
\end{tabular}

Примітка: складено автором за даними («Valoviy regionalniy produkt za 2013 rik», 2013) 
Розвиток підприсмництва в Карпатському регіоні за 2011 - 2014pp.

\begin{tabular}{|c|c|c|c|c|c|}
\hline Рік & Україна & Закарпатська обл. & $\begin{array}{c}\text { Івано-Франківська } \\
\text { обл. }\end{array}$ & $\begin{array}{c}\text { Львівська } \\
\text { обл. }\end{array}$ & $\begin{array}{c}\text { Чернівецька } \\
\text { обл. }\end{array}$ \\
\hline \multicolumn{6}{|c|}{ Кількість підприємств, одиниць } \\
\hline .2011 & 375695 & 5574 & 7643 & 16675 & 3731 \\
\hline 2012 & 364935 & 5627 & 7675 & 17332 & 3994 \\
\hline 2013 & 393327 & 6024 & 7996 & 18762 & 4160 \\
\hline 2014 & 341004 & 6071 & 7945 & 18582 & 4065 \\
\hline \multicolumn{6}{|c|}{ Кількість малих підприємств, одиниць } \\
\hline 2011 & 354283 & 5246 & 7310 & 15695 & 3517 \\
\hline 2012 & 344048 & 5322 & 7352 & 16368 & 3793 \\
\hline 2013 & 373809 & 5741 & 7668 & 17849 & 3968 \\
\hline 2014 & 324598 & 5799 & 7652 & 17718 & 3897 \\
\hline \multicolumn{6}{|c|}{ Питома вага МП у \% до загальної кількості підприємств регіону } \\
\hline 2011 & 94,3 & 94,1 & 95,6 & 94,1 & 94,3 \\
\hline 2012 & 94,3 & 94,6 & 95,8 & 94,4 & 95,0 \\
\hline 2013 & 95,0 & 95,3 & 95,9 & 95,2 & 95,4 \\
\hline 2014 & 95,2 & 95,5 & 96,3 & 95,4 & 95,9 \\
\hline \multicolumn{6}{|c|}{ Обсяг реалізованої продукції, млрд грн } \\
\hline 2011 & 4202,45 & 32,06 & 39,63 & 131,61 & 16,63 \\
\hline 2012 & 4459,82 & 34,31 & 44,21 & 143,51 & 18,91 \\
\hline 2013 & 4334,45 & 36,98 & 53,70 & 144,17 & 18,87 \\
\hline 2014 & 4459,70 & 43,95 & 50,52 & 166,39 & 21,71 \\
\hline \multicolumn{6}{|c|}{ Питома вага обсягу реалізованої продукції МП у загальному обсязі реалізованої продукції, \% } \\
\hline 2011 & 15,2 & 19,9 & 21,6 & 19,3 & 34,8 \\
\hline 2012 & 16,0 & 19,9 & 20,7 & 19,2 & 32,5 \\
\hline 2013 & 16,6 & 17,8 & 18,2 & 19,8 & 32,7 \\
\hline 2014 & 16,9 & 19,8 & 24,3 & 20,8 & 36,0 \\
\hline
\end{tabular}

Джерело : складено автором за даними (State Statistics Service of Ukraine [SSSU], 2016)

Найнижчий вклад у ВРП України серед областей Карпатського регіону має Чернівецька область - 0,9\% («Valoviy regionalniy produkt za 2013 rik», 2013). Ї̈̈ частка у ВРП країни за розглянутий період не змінилась, однак в абсолютному значенні приріст склав 3,8 млрд грн.

Важлива характеристика рівня розвитку господарського (економічного) потенціалу регіону - це величина ВРП, розрахованого на душу населення регіону. Необхідно зазначити, що розмір ВРП Карпатського регіону в розрахунку на одну особу населення в 1,5 рази нижче, ніж середнє значення по Україні 20289 грн і 33473 грн відповідно (рис.1.) («Valoviy regionalniy produkt za 2013 rik», 2013) .

Найнижчі показники в Закарпатській і Чернівецькій областях: 17044 грн і 15154 грн на одну особу відповідно, що удвічі нижче середнього значення по Україні і на чверть нижче середнього значення по Карпатському регіону (рис.1).Навіть досить успішна Львівська область за цим показником значно поступається середньому значенню по Україні: 24022 грн і 33473 грн на одну особу відповідно («Valoviy regionalniy produkt za 2013 rik», 2013).
Одними з головних інституціональних чинників розвитку потенціалу регіону можна вважати перетворення відносин власності, ступінь розвитку малого підприємництва. Саме підприємництво забезпечує виробництво необхідних товарів (робіт і послуг), зайнятість населення та створення нових робочих місць у регіоні, залучення інвестиційних ресурсів тощо.

Для сфери підприємництва в регіоні характерна значна частка малих підприємств. Їх питома вага в загальній чисельності підприємств регіону перевищує середнє значення показника по Україні за весь досліджуваний період (табл.2).

У Карпатському регіоні сформовано розвинуту інфраструктуру підтримки підприємництва: 39 бізнес-центрів, 328 небанківських фінансовокредитних установ, 54 інвестиційні та інноваційні фонди і компанії, 155 консультативних установ, 257 громадських об'єднань суб' єктів підприємництва, 88 координаційних рад із питань підприємництва (Libanova, Hvesik, 2014).

Однак інфраструктура підтримки підприємництва використовується не достатньо ефективно, про що свідчить мала загальна кількість суб'єктів МП на 


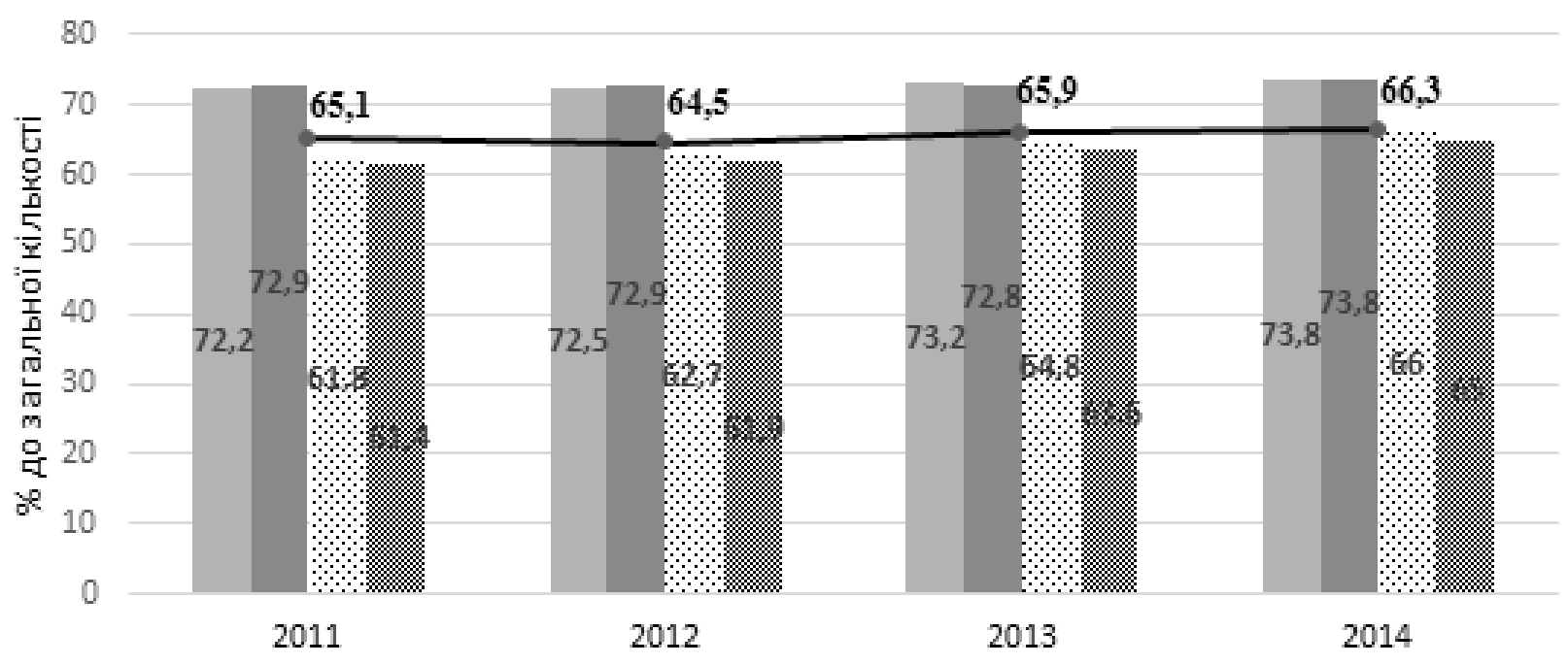

Закарпатська область

Івано-Франківська область

Львівська область

жам Чернівецька область

—-Україна

Рис.2. Підприємства, які одержали прибуток, у \% від загальної кількості підприємств регіону.

10 тис. осіб наявного населення регіону. За 2011 2014 роки кількість МП на 10 тис. осіб населення зросла з 52,3 до 57,6, що значно менше відповідного значення показника в Україні - 77,5 і 75,5 МП на 10 тис. осіб населення. Найбільша кількість МП регіону зосереджена в переробній промисловості, сільському господарстві (лісовому і рибному господарстві), оптовій та роздрібній торгівлі, транспорті, туризмі. Найбільша питома вага МП у загальному обсязі реалізованої продукції (товарів та послуг) у Чернівецькій області. За 2011 - 2014 роки їх частка реалізованої продукції (товарів, послуг) удвічі перевищувала середній показник по країні: 36 і 16,9 \% у 2014 році відповідно (State Statistics Service of Ukraine [SSSU], 2016) . Важливий для аналізу впливу інституціональних чинників на розвиток господарського потенціалу регіону є рівень прибутковості та рентабельності діяльності підприємств. Питома вага підприємств, які одержали прибуток у Карпатському регіоні, значно перевищує кількість прибуткових підприємств у середньому в Україні (рис.2). Найбільша кількість прибуткових підприємств в Івано-Франківській і Закарпатській областях $73,8 \%$ відповідно (State Statistics Service of Ukraine [SSSU], 2016).

Ефективність ринку праці характеризують показники економічної активності населення в працездатному віці (рис.3) і рівень безробіття, середня заробітна плата в регіоні.

За 2011 - 2015 роки кількість економічно активного населення Карпатського регіону, на відміну від загального показника по Україні, зросла на 71,1 тис. осіб(з 2543,4 тис. до 2614,5 тис.), а рівень економічної активності населення працездатного віку майже не змінився (рис.3) («Monitoring sotsialnoekonomichnogo rozvitku regioniv za sichen-veresen», 2015, State Statistics Service of Ukraine [SSSU], 2016) .

Зауважимо, що в розглянутому періоді рівень економічної активності населення працездатного віку в Карпатському регіоні нижчий ніж відповідний показник в Україні: його значення за січень - вересень 2015 року - 67,2 і 71,7 \% відповідно («Monitoring sotsialno-ekonomichnogo rozvitku regioniv za sichenveresen», 2015).

Розвиток малого підприємництва зумовив зміну структури зайнятості населення в регіоні: зменшення зайнятості у виробничій сфері та збільшення в торгівлі, транспорті та сфері туризму.

Рівень безробіття у Закарпатській та Чернівецькій областях перевищує середнє значення цього показника в Україні. У січні - вересні 2015рокурівень безробіття в Чернівецькій області був найвищим - 10,3 \% населення працездатного віку $(9,4$ \% в Україні) («Monitoring sotsialno-ekonomichnogo rozvitku regioniv za sichen-veresen», 2015).

Серед областей Карпатського регіону тільки у Львівській області рівень безробіття нижча середній по Україні. Якщо в Україні за 2011 - 2015 роки рівень безробіття зріс з 8,6 до 9,4 \%, то у Львівській області - 3 8,3 до 8,5\% відповідно («Monitoring sotsialnoekonomichnogo rozvitku regioniv za sichen-veresen», 2015, State Statistics Service of Ukraine [SSSU], 2016) . 
Розмір середньої заробітної плати в Карпатському регіоні за січень -вересень 2015року на 814 грн менший, ніж у цілому по Україні: 3282 грн і 4096 грн в 1,5 рази менший відповідного значення в Україні.

Найбільший рівень доходу в розрахунку на одну особу у Львівській області, однак його розмір ста-

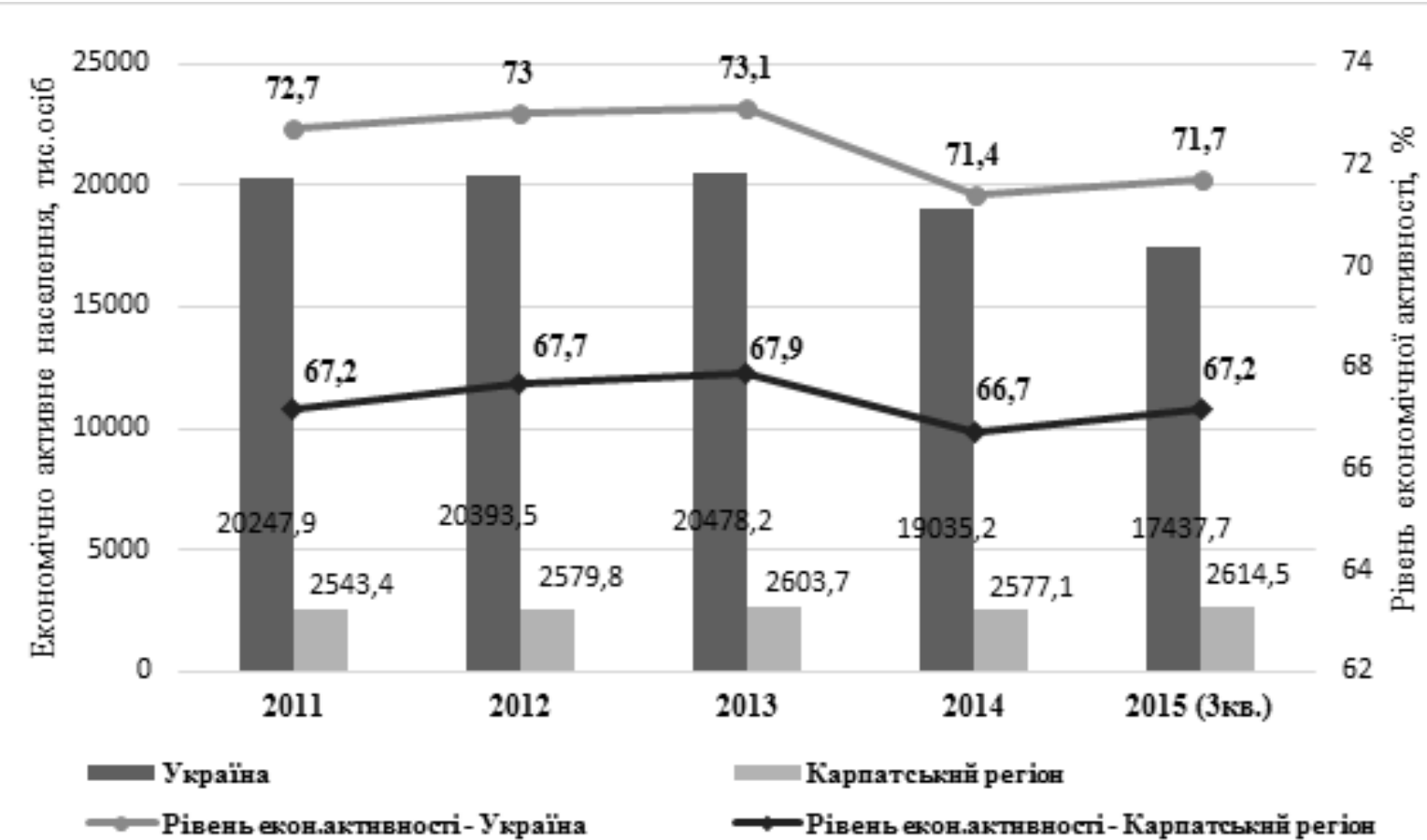

Рис.3. Економічна активність населення працездатного віку України і Карпатського регіону у 2011 - 2015 pр.

відповідно. При цьому найменший розмір середньої заробітної плати за січень - вересень 2015 року в Чернівецькій області - 2955 грн, а найбільший у Львівській - 3559 грн. (State Statistics Service of Ukraine [SSSU], 2016).

Для розвитку господарського потенціалу регіонів в умовах децентралізації великого значення набуває розмір доходів місцевих бюджетів у розрахунку на одну особу. Зазначимо, що доходи місцевих бюджетів у Карпатському регіоні в розрахунку на одну особу населення за 2014 - 2015 роки зросли в усіх областях: у Закарпатській та Чернівецькій - 3700 до 1000 грн., Івано-Франківській - з 900 до 1200 грн, Львівській - 1000 до 1500 грн (State Statistics Service of Ukraine [SSSU], 2016).

Про недостатнє використання економічного потенціалу регіону свідчить низький рівень доходів населення. Наявний дохід у розрахунку на одну особу в Карпатському регіоні менший, ніж відповідний середній показник в Україні (рис.4).

Найменший дохід в розрахунку на одну особу спостерігається в Закарпатській та Чернівецькій областях. Цей показника в згадуваних областях майже новить лише 88\% загальноукраїнського значення у 2014 році (максимальне співвідношення було у 2010 році - 89,3\%) (State Statistics Service of Ukraine [SSSU], 2016).

Одна з головних конкурентних переваг розвитку господарського потенціалу Карпатського регіону $є$ вигідне територіальне розташування. Регіон межує з Польщею, Румунією, Молдовою, Угорщиною та Словаччиною.

Прикордонне співробітництво сприяє інвестиційному розвитку регіону. За 2014 - 2015 роки обсяг капітальних інвестицій у розрахунку на одну особу зріс в усіх областях Карпатського регіону: у Закарпатській - 31 406,3 грн до 1839,5 грн, у Івано-Франківській - 33096 грн до 3 295,6 грн, у Львівській - 32 312,6 грн до 2 816,6 грн, у Чернівецькій - 31 072,4 грн до 1 348,3 грн («Monitoring sotsialno-ekonomichnogo rozvitku regioniv za sichenveresen», 2015).

В останні роки в Карпатському регіоні активізувалися виробництво сільськогосподарської продукції, оптова та роздрібна торгівля, розвиток туристичної галуззі, будівництво, зокрема у Львівській області - 

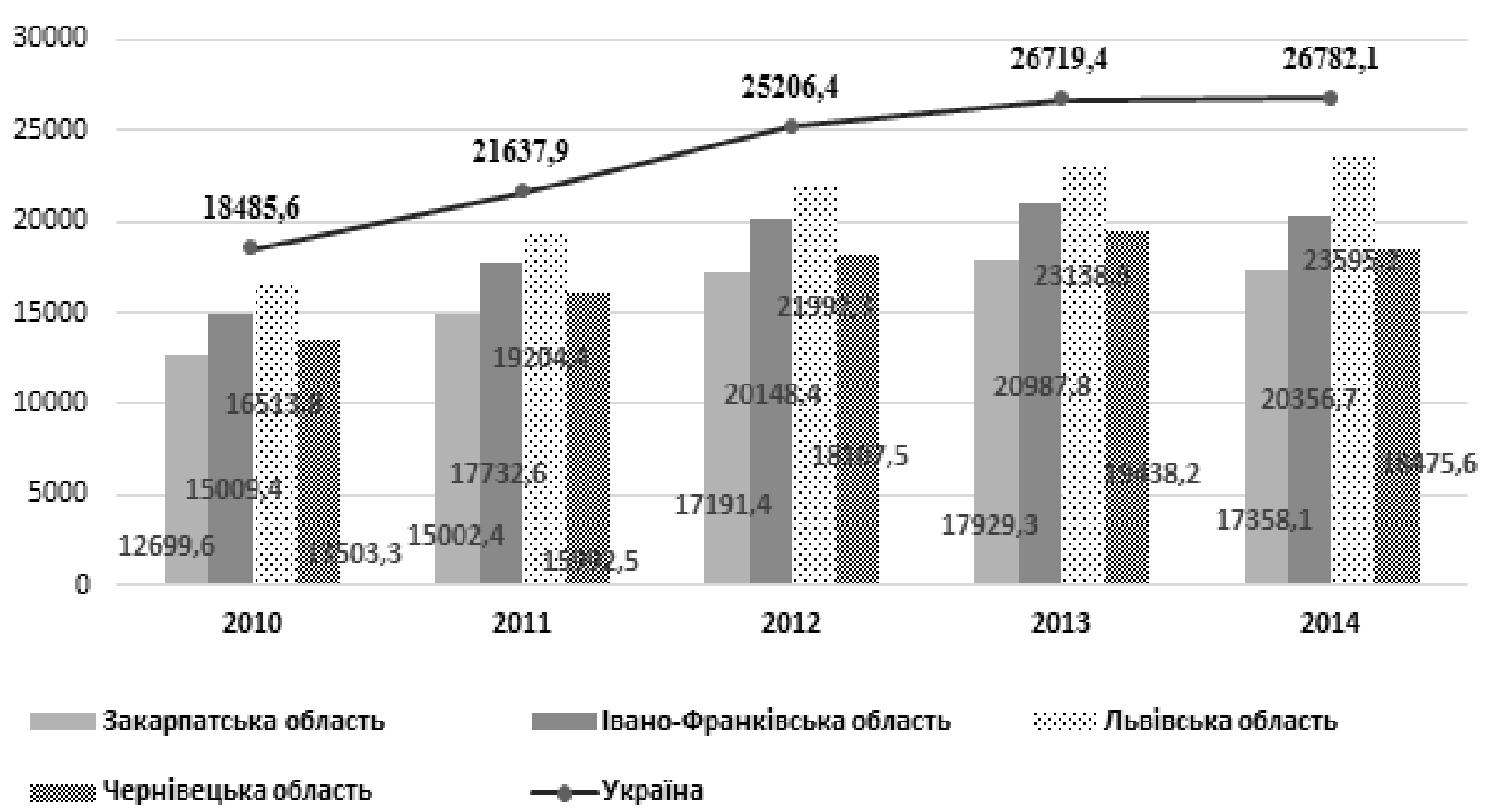

Рис.4. Наявний дохід у розрахунку на одну особу населення України і Карпатського регіону у 2010 - 2014pp., грн.

обсяг будівельних робіт у розрахунку на одну особу населення зріс в 1,38 раза, з 600,3 грн у 2014 р. до 829,2 грн у 2015 році.

Обсяг обороту роздрібної торгівлі Карпатського регіону за 2011 - 2015 роки зріс на $83 \%$, або на 60 440,4 млн грн (з 72 447,6 млн. грн. до 132888 млн. грн.), питома вага регіону в обсязі роздрібної торгівлі України зросла з 10 до13\% відповідно (State Statistics Service of Ukraine [SSSU], 2016).

Слід зауважити, що соціально-економічна нестабільність, анексія Криму, воєнні дії на Сході країни зумовили зменшення обсягу прямих іноземних інвестицій в економіку України та іiї регіонів у 2014 - 2015роках. Обсяг ПІІ в Карпатський регіон у розрахунку на одну особу зменшився з 410,8 дол. США до 360,57 дол. США відповідно («Monitoring sotsialno-ekonomichnogo rozvitku regioniv za sichenveresen», 2015).

Важливий стратегічний напрям розвитку господарського потенціалу Карпатського регіону туристично-рекреаційна сфера, зокрема, розвиток сільського, зеленого, гірського та екстремального туризму («Ekonomika regioniv u 2015 rotsi», 2015 )

Необхідно зазначити, що повноцінний розвиток туристичної і рекреаційної сфери істотно впливає на такі сектори економіки, як транспорт, торгівля, зв'язок, будівництво, сільське господарство, виробництво товарів широкого вжитку і $є$ одним $з$ найбільш перспективних напрямів структурної перебудови економіки Карпатського регіону («Ekonomika regioniv u 2015 rotsi», 2015 ).

Висновки. Проведене дослідження дозволило виявити такі особливості впливу інституціональних чинників на формування і розвиток господарського потенціалу Карпатського регіону:

- регіон значно відстає від інших регіонів України за показниками ВРП і ВРП в розрахунку на одну особу, що вказує на низьку ефективність виробництва;

- у регіоні сформовано розвинуту інфраструктуру підтримки розвитку підприємництва, що зумовило значну частку МП в загальній кількості підприємств регіону (понад 95,3 \%), однак кількість МП на 10 тис. осіб населення значно менша відповідного загальноукраїнського показника 57,6 і 75,5 підприємств відповідно;

- частка прибуткових підприємств у регіоні значно більша ніж у середньому в Україні;

- ефективність ринку праці регіону недостатня, що зумовлено низьким рівнем економічної активності населення працездатного віку, високим рівнем безробіття та низькою середньою заробітною платою;

- зростання доходів місцевих бюджетів у розрахунку на одну особу було недостатнє і не сприяло збільшенню наявних доходів населення;

- у регіоні недостатньо розвинуті інститути підтримки конкурентного середовища, фінансового ринку, інноваційного розвитку; 
- розвиток прикордонного співробітництва збільшив обсяги капітальних інвестицій, виробництва сільськогосподарської продукції, оптової та роздрібної торгівлі, туристичної галузі, будівництва.

\section{Бібліографічні посилання}

Doroshenko Yu. A., 2006.Sostav i struktura ekonomicheskogo potentsiala [The composition and structure of economic potential]. ITD “UniversityBook”,Sumy, 135-148 (in Russian)

Ekonomika regioniv u 2015 rotsi: novirealiyi i mozhlivostI v umovah zapochatkovanih reform. [The region's economy in 2015: new realities and opportunities in terms of reforms initiated]. NISD, Kiev.(in Ukrainian)

Libanova E. M., Hvesik M.A., 2014. Sotsialno-ekonomIchniy potentsial stalogo rozvitku Ukrayini ta yiyi regioniv: natsionalna dopovid [The socio-economic potential of sustainable development of Ukraine ditsregions: national report]. DU IEPSR NAS Ukraine,Kiev. (in Ukrainian).

Monitoring sotsialno-ekonomichnogo rozvitku regioniv za sichen-veresen 2015 roku (reytingova otsinka). [Monitoring of socio-economic development in January-September 2015 (grade)]. February, 10, 2016, from http://www. minregion.gov.ua (in Ukrainian)

Otchet o konkurentosposobnosti regionov Ukrainyi 2013: navstrechu ekonomicheskomu rostu i protsvetaniyu [Report on Competitiveness of Regions of Ukraine 2013: meettheeconomic growthand prosperity]. Foundation «Effective Management», Kiev. (in Russian).

Semenov V. F., 2008. Regionaln aekonomika. [Regional economy]. SB «Lesya», Kiev. (in Ukrainian).

Soldak M. A. Institutsionalnyiy potentsial promyishlennyihre gionov Ukrainyi. [The institutional capacity of the industrial regions of Ukraine]. Ekonomika promyishlennosti. no. 4(68). (2014): 31-48.(in Russian)

State Statistics Service of Ukraine (official site). February, 18, 2016, from http://www.ukrstat.gov.ua (inUkrainian) Valoviy regionalniy produkt za 2013 rik: Statistichniy zbirnik. [Grossregionalproduct]. February, 16, 2016, from http:// www.ukrstat.gov.ua (in Ukrainian) 